\title{
Anti-inflammation effects of hydrogen saline in LPS activated macrophages and carrageenan induced paw oedema
}

\author{
Zheng Xu, Jiangrui Zhou, Jianmei Cai, Zhen Zhu, Xuejun Sun and Chunlei Jiang*
}

\begin{abstract}
Background: Oxidative stress is thought to play an important role in the pathogenesis of inflammation. Recent studies have found that hydrogen gas has the effect of eliminating free radicals. Whether hydrogen saline (more convenient to be used than hydrogen gas) has the anti-inflammation effect or not is still unknown.

Methods: Carrageenan-induced paw oedema and LPS-activated macrophages are studied in this article. Injection of carrageenan into the foot of a mouse elicited an acute inflammatory response characterized by increase of foot volume and infiltration of neutrophils. While tumor necrosis factor $\alpha(T N F-\alpha)$ secreted by activated macrophages was determined by ELISA and real-time PCR.
\end{abstract}

Results: All parameters of inflammation (foot volume, infiltration of neutrophils, amount of TNF- $\alpha$ and the level of TNF- $\alpha$ 's mRNA) were attenuated by the hydrogen saline treatment.

Conclusion: As a more convenient way than inhaling $\mathrm{H}_{2}$, hydrogen saline exhibits a protective effect against inflammation and it might provide a novel therapeutic approach for inflammatory diseases.

Keywords: hydrogen saline, macrophages, TNF-a, anti-inflammation, carrageenan

\section{Background}

Oxidative stress is thought to play an important role in the pathogenesis of inflammation not only through direct injurious effects, but also by involvement in molecular mechanisms [1]. Among the complicated factors involved in the process of inflammation, reactive oxygen species (ROS) and reactive nitrogen species (RNS), such as the hydroxyl radical $\left({ }^{\circ} \mathrm{OH}\right)$, superoxide anion $\left(\mathrm{O}_{2}{ }^{-}\right)$, hydrogen dioxide $\left(\mathrm{H}_{2} \mathrm{O}_{2}\right)$, nitric oxide (NO) and peroxynitrite $\left(\mathrm{ONOO}^{-}\right)$, appear to be critical elements. There is a large amount of evidence showing that the production of reactive species such as $\mathrm{O}_{2}{ }^{-*}, \mathrm{H}_{2} \mathrm{O}_{2}$, and ${ }^{\circ} \mathrm{OH}$ occurs at the site of inflammation and contributes to tissue damage $[2,3]$. By using inhibitors of NOS, the severity of inflammation was reduced, which demonstrates the role of $\mathrm{NO}^{*}$ in the pathogenesis associated with various models of inflammation [4-6]. In addition to $\mathrm{NO}^{\circ}, \mathrm{ONOO}^{-}$is also generated during inflammation damage $[3,6]$. The

\footnotetext{
* Correspondence: cljiang@vip.163.com

Department of Nautical Medicine, Second Military Medical University, 800 Xiangyin Road, Shanghai 200433, P.R. of China
}

involvement of $\mathrm{ONOO}^{-}$in these conditions is strongly manifested by direct measurements. There is immunocytochemical documentation (increased nitrotyrosine immunoreactivity in the inflamed tissues) of augmented $\mathrm{ONOO}^{-}$production in many inflammation diseases, such as ileitis [7], endotoxin-induced intestinal inflammation [8] and arthritis[9]. Furthermore, the ability of $\mathrm{ONOO}^{-}$to cause severe colonic inflammation has also been documented [10]. Whereas, detoxification system for ${ }^{\circ} \mathrm{OH}$ and $\mathrm{ONOO}^{-}$in vivo has not been found; therefore, scavenging of ${ }^{\circ} \mathrm{OH}$ and $\mathrm{ONOO}^{-}$turns out to be a vital antioxidant process[11]. It has been reported recently that $\mathrm{H}_{2}$ selectively reduced ${ }^{\circ} \mathrm{OH}$ and $\mathrm{ONOO}^{-}$ [12]. So, as a free radical scavenger, $\mathrm{H}_{2}$ may have the effect of anti-inflammation. Recently, molecular hydrogen has been proved effective in curing concanavalin Ainduced hepatitis[13] and colon inflammation induced by dextran sodium sulfate[14]. However, inhalation of hydrogen gas may not be convenient for therapeutic use. A brief report has suggested that consumption of water containing hydrogen at a saturated level
C Biomed Central

(c) 2012 Xu et al; licensee BioMed Central Ltd. This is an Open Access article distributed under the terms of the Creative Commons Attribution License (http://creativecommons.org/licenses/by/2.0), which permits unrestricted use, distribution, and reproduction in any medium, provided the original work is properly cited. 
(hydrogen saline) reduces oxidative stress in rats[15]. Thus, we expect to examine the effects of hydrogen saline on inflammation models.

Macrophages are considered to be an essential participant in inflammation [16]. When activated by endotoxin, macrophages produce inflammatory cytokines, which in turn activate other macrophages and other nearby cells to promote more inflammatory cytokines. Tumor necrosis factor-alpha, as one of these inflammatory cytokines, has a decisive function in the process of inflammation[17], and could represent the severity of inflammation.

In this study, we expect to examine whether the hydrogen saline has the anti-inflammation effect on both animal and cellular inflammation models.

\section{Methods}

\section{Hydrogen saline}

Molecular hydrogen $\left(\mathrm{H}_{2}\right)$ dissolved in saline under high pressure $(0.6 \mathrm{MPa})$ to a supersaturated level for 2 hours [18]. Hydrogen saline was freshly prepared every week. The hydrogen concentration was detected by gas chromatography, the concentration of hydrogen being 0.6 $\mathrm{mM}$ in each experiment. Hydrogen saline degassed by gentle stirring was used for control animals.

\section{Animals and Carrageenan-induced paw oedema}

Male BALB/c mice (20-25 g) were housed in a controlled environment and provided with standard rodent chow and water. To test inhibitory effects on acute inflammation in an animal model, paw edema was induced by subcutaneous injection of $0.05 \mathrm{~mL}$ of carrageenan (1\%) into the right hind paw, as was previously described [19]. Right after the carrageenan administration, the animals received an i.p. injection of either saline $(5 \mathrm{ml} / \mathrm{kg})$ or hydrogen saline $(5 \mathrm{ml} / \mathrm{kg})$. The paw volume was measured by a volume measuring instrument(YLS-7B from Gene\&I) at each hour point after edema induction. The increase in percentage of paw volume was calculated based on the volume difference between the normal and abnormal paws (with or without carrageenan injection). Seven animals per group were tested. The Animal and Ethics Review Committee at the Second Military Medical University evaluated and approved the protocol used in this study.

\section{Histological examination}

After $4 \mathrm{~h}$ of carrageenan treatment, mice were sacrificed, and the tissue of the paws was removed and fixed in alfac solution. Each sample was embedded in paraffin wax, sectioned at $5 \mu \mathrm{m}$ and stained with hematoxylineosin. A representative area was selected for qualitative light microscopic analysis of the inflammatory cellular response with a $20 \times$ objective [20]. Five slices from each animal were analyzed and a minimum of three animals for each treatment was taken.

\section{The detection of 3-nitrotyrosine(3 -NT) in the plasma}

3-nitrotyrosine(3-NT) is the metabolite of the $\mathrm{ONOO}^{-}$, and it is stable and easier to be detected than $\mathrm{ONOO}^{-}$. What's more, it can reflect the concentration of $\mathrm{ONOO}^{-}$ - After $4 \mathrm{~h}$ of carrageenan treatment, mice were sacrificed. The blood was collected and centrifuged at 3000 rpm. 3-NT concentration was determined in the cell free supernatant by enzyme-linked immunosorbent assay(ELISA). Antibody-matched pairs and respective standards were purchased from R\&D system(Minneapolis, Minn, U.S.A), and were used according to the manufacturer's instructions. The sensitivity for the 3-NT ELISA assay is $2 \mathrm{nmol} / \mathrm{L}$.

\section{Tissue MPO activity assay}

The activity of tissue MPO was assessed $4 \mathrm{~h}$ after injection of carrageenan into the mouse's right hind paw. Samples were placed in $0.75 \mathrm{ml}$ of $80 \mathrm{mM}$ phosphatebuffered saline (PBS), pH 5.4, containing 0.5\% hexadecyltrimethylammonium bromide, and were then homogenized $\left(45 \mathrm{~s}\right.$ at $\left.0^{\circ} \mathrm{C}\right)$ in a motor-driven homogenizer. The homogenate was decanted into a microfuge tube, and the vessel was washed with a second $0.75 \mathrm{ml}$ aliquot of hexadecyltrimethylammonium bromide in buffer. The wash was added to the tube, and the $1.5 \mathrm{ml}$ sample was centrifuged at $12,000 \times \mathrm{g}$ at $4^{\circ} \mathrm{C}$ for $15 \mathrm{~min}$. Triplicate $30 \mu \mathrm{l}$ samples of the resulting supernatant were added to 96 -well microtitre plates. For assay, $200 \mu \mathrm{l}$ of a mixture containing $100 \mu \mathrm{l}$ of $80 \mathrm{mM}$ PBS, pH 5.4, $85 \mu \mathrm{l}$ of $0.22 \mathrm{M} \mathrm{PBS}, \mathrm{pH} 5.4$, and $15 \mu \mathrm{l}$ of $0.017 \%$ hydrogen peroxide were added to the wells. The reaction was started with the addition of $20 \mu \mathrm{l} 18.4 \mathrm{mM}$ tetramethylbenzidine $\mathrm{HCl}$ in dimethylformamide. Plates were incubated at $37^{\circ} \mathrm{C}$ for $3 \mathrm{~min}$, and then the reaction was stopped by the addition of $30 \mu \mathrm{l}$ of $1.46 \mathrm{M}$ sodium acetate. $\mathrm{pH}$ 3.0. Enzyme activity was determined colorimetrically using a plate reader (ELX800, BioTech Instruments, Inc.) set to measure absorbance at $630 \mathrm{~nm}$ and expressed as mOD/ mg tissue.

\section{Isolation of murine peritoneal macrophages}

Macrophages were prepared from BALB/c mice as was previously described [21]. Briefly, peritoneal macrophages were harvested from 2 to $3 \mathrm{BALB} / \mathrm{c}$ mice, which had been injected intraperitoneally with $1 \mathrm{ml}$ of thioglycollate three days before sterile peritoneal lavage with 5 ml of Hank's balanced salt solution. The collected cells were seeded and cultured in RPMI1640 containing 10\% heat-inactivated FBS, $100 \mathrm{IU} / \mathrm{ml}$ penicillin and $100 \mu \mathrm{g} /$ $\mathrm{ml}$ streptomycin at a density of $5 \times 10^{6}$ cells/well. The cells were allowed to adhere for $1 \mathrm{~h}$ to a 48 -well culture 
plate at $37^{\circ} \mathrm{C}$ in a $5 \% \mathrm{CO}_{2}$ incubator. Then the cultures were washed twice with RPMI1640 to remove nonadherent cells prior to the addition of $400 \mu \mathrm{l}$ of fresh RPMI1640 containing 10\% FBS. The purity of the adherent macrophages was assessed by Giemsa staining(> 95\%).

\section{RT-PCR}

Total RNA was isolated from macrophages using TriZol Reagent. Total RNA was reverse-transcribed into cDNA and then PCR amplification of the CDNA was performed. The forward and reverse primer sequences of PCR primers were as follows: murine TNF- $\alpha$ : F 5'-CCC TCA CAC TCA GAT CAT CTT CT-3', R 5'-GCT ACG ACG TGG GCT ACA G-3'; murine $\beta$-actin: F 5'-CTT TGC AGC TCC TTC GTT GC-3', R 5'-ACG ATG GAG GGG AAT ACA GC-3' [22]. An aliquot of the total RNA was reverse-transcribed by RAV2 reverse transcriptase (20 U/ul, TAKARA, Japan) and the oligo$\mathrm{dT}$ primer $(300 \mathrm{pmol})$ in a total volume of $40 \mathrm{ul}$ reaction according to the manufacturer's instructions. cDNAs were analyzed immediately or stored at $-20^{\circ} \mathrm{C}$ until use. Real-time PCR assay was carried out with LightCycler (Roche Diagnostics.Germany) using LightCycler FastStart DNA Master SYBR Green I (Roche Diagnostics). $1 \mathrm{ul}$ of cDNA was added to a $19 \mathrm{ul}$ of reaction mixture including $\mathrm{MgCl}_{2}$ at the optimal concentration, $20 \mathrm{pmol}$ of each primer and 2 ul of a LightCycler FastStart DNA Master SYBR Green I. Then the mixture was incubated in LightCycler under the following conditions: at $95^{\circ} \mathrm{C}$ for $10 \mathrm{~min}$ for denaturation, followed by 50 cycles of $94^{\circ}$ $\mathrm{C}$ for 1 second, each of the optimal annealing temperature for 5 seconds, $72^{\circ} \mathrm{C}$ for 10 seconds and finally cooling to $40^{\circ} \mathrm{C}[23]$. We use the double stranded DNAbinding dye SYBR Green I to estimate the expression level of cytokine mRNA[24]. Transcripts of beta-actin, as a housekeeping gene, were quantified as endogenous RNA of reference to normalize each sample. Relative quantities were estimated by the delta-delta-Ct method. The results were normalized as relative expression in which the average value of the TNF- $\alpha$ mRNA was divided by the average value of beta-actin mRNA.

\section{Cell culture and detection of TNF- $\alpha$ in the supernatant of the activated macrophages}

RAW 264.7 murine macrophages were obtained from the American Type Culture Collection (Manassas, USA). These cells and murine peritoneal macrophages were cultured in a 48-well culture plate with $400 \mu \mathrm{l}$ RPMI1640 in each well and maintained at sub-confluence in a $95 \%$ air and $5 \% \mathrm{CO}_{2}$ humidified atmosphere at $37^{\circ} \mathrm{C}$ [25]. The medium used as the routine subculture was RPMI1640 supplemented with $10 \%$ fetal bovine serum (FBS), penicillin (100 units/mL) and streptomycin $(100 \mu \mathrm{g} / \mathrm{mL})$. TNF- $\alpha$ concentration was determined in the cell free supernatant obtained after $4 \mathrm{~h}$ macrophages co-culture with LPS $(100 \mathrm{ng} / \mathrm{ml})$ by enzyme-linked immunosorbent assay(ELISA). Antibody-matched pairs and respective standards were purchased from R\&D system(Minneapolis, Minn, U.S.A), and were used according to the manufacturer's instructions. The sensitivity for the TNF ELISA assay is $7 \mathrm{pg} / \mathrm{ml}$.

\section{Statistics}

Statistical comparisons among the groups were assessed by one-way analysis of variance (ANOVA). When F ratios were significant $(\mathrm{P}<0.05)$, LSD 's post hoc tests between two groups were done using SPSS Statistics (SPSS Inc.). $\mathrm{P}<0.05$ was considered statistically significant.

\section{Results}

Effects of hydrogen saline in carrageenan-induced paw oedema

In order to determine the anti-inflammation activity of hydrogen saline in acute-phase inflammation in vivo, a carrageenan-induced paw oedema experiment was conducted. Hydrogen saline showed a remarkable inhibitory activity in carrageenan-induced paw oedema after carrageenan injection. The time-dependent curve shows that the paw swelling ratio will rise till 4 hours after carrageenan injection. (Figure 1A) Hydrogen saline showed bell shaped effect of down-regulating carrageenan-induced paw swelling, compared with the vehicle control group, which received an equal volume of vehicle only (saline). (Figure 1A.B). And $5 \mathrm{ml} / \mathrm{Kg}$ was the most effective dose, which was similar to the results that our lab had observed (5 $\mathrm{ml} / \mathrm{Kg}$ was the proper dose for the effects)[18]. It has been reported that the bell shaped phenomenon also exists in the hydrogen gas's effect of anti-ischemia-reperfusion injury[12]. This bell shaped phenomenon is quite hard to explain now and its mechanism needs to be studied in our further experiments.

\section{Effects of hydrogen saline on histological changes} associated with carrageenan-induced mouse paw oedema Figure 2 shows some representative photos from the histological changes in the paw tissues following the subplantar injection of carrageenan $(0.05 \mathrm{~mL} / \mathrm{paw})$ and the antiinflammation effects of hydrogen saline. The $4 \mathrm{~h}$ peak of the carrageenan inflammatory response was found to be associated with subcutaneous oedema along with the heavy infiltration of neutrophils at the site of injection. The treatment of animals with hydrogen saline exhibited a significant decrease in the number of cellular infiltrates.

\section{Effects of hydrogen saline on the 3-NT in the plasma}

$\mathrm{ONOO}^{-}$is unstable and can be deoxidized very soon. 3NT is stable and easy to be detected, and it can reflect 

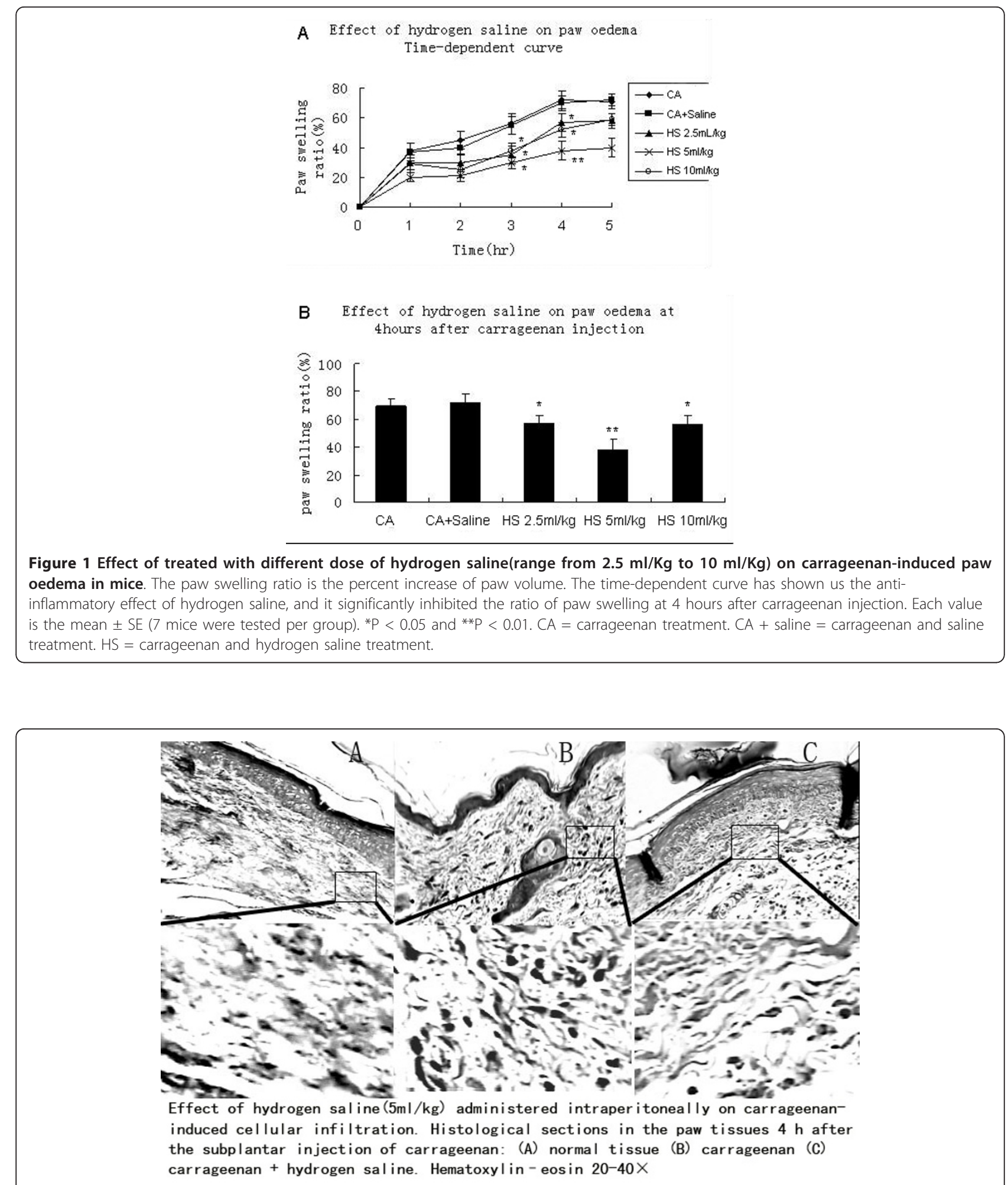

Figure 2 Effect of hydrogen saline $(5 \mathrm{ml} / \mathrm{kg})$ administered intraperitoneally on carrageenan-induced cellular infiltration. Histological sections in the paw tissues $4 \mathrm{~h}$ after the subplantar injection of carrageenan: (A) normal tissue (B) carrageenan (C) carrageenan + hydrogen saline. Hematoxylin-eosin 20-40x, 5 um sections. Five slices from each animal were analyzed and a minimum of three animals for each treatment were taken. 


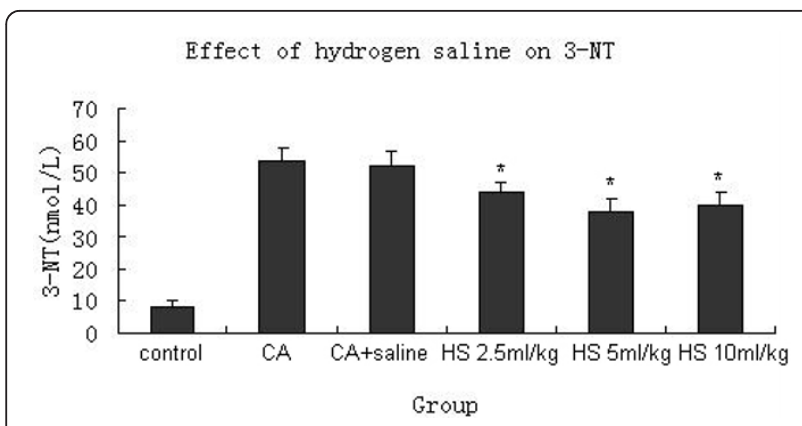

Figure 3 Hydrogen saline(range from $2.5 \mathrm{ml} / \mathrm{kg}$ to $10 \mathrm{ml} / \mathrm{kg}$ ) decreased 3-nitrotyrosine(3-NT) concentration in the serum. Serum was collected $4 \mathrm{~h}$ after carrageenan treatment. 3-NT was measured with an ELISA(7 mice were tested per group).*P $<0.05$ compared with $C A+$ saline group. $C A=$ carrageenan treatment. $C A+$ saline $=$ carrageenan and saline treatment. $\mathrm{HS}=$ carrageenan and hydrogen saline treatment.

the concentration of $\mathrm{ONOO}^{-}$. Figure 3 and Table 1 show that the hydrogen saline can decrease the concentration of 3-NT in the plasma.

\section{Effect of the hydrogen saline on MPO activity}

The neutrophil migration into carrageenan-stimulated mouse paws was indirectly determined by means of MPO activity. Treatment with different doses of hydrogen saline significantly prevented the increase in MPO activity induced by carrageenan (Figure 4 , Table 1 ).

\section{RT-PCR}

Expression of activated macrophage mRNA was determined $1 \mathrm{hr}$ after the treatment of hydrogen saline or saline. TNF- $\alpha$ mRNA of activated macrophages treated with hydrogen saline was lower than that of those treated with saline.(Figure 5)

\section{Effects of hydrogen saline on TNF- $\alpha$ produced by LPS-} activated macrophages

The production of TNF- $\alpha$ from activated macrophages which were treated with saline proved much more than that of those treated with hydrogen saline. This result was similar in both murine peritoneal macrophages
(Figure 6A) and RAW 264.7 murine macrophages (Figure $6 \mathrm{~B}$ ) indicating that hydrogen saline was able to inhibit the TNF- $\alpha$ production of macrophages.

\section{Discussion}

In this study, hydrogen saline inhibited carrageenaninduced paw oedema, and suppressed the production of TNF- $\alpha$ by activated macrophages. The anti-inflammation effects of hydrogen saline on inflammation models seem related to its function of scavenging radicals and downregulating TNF- $\alpha$ production, because free radicals and TNF- $\alpha$ play a critical role in the process of inflammation. These observations indicate that the hydrogen saline may have clinical potentials for the treatment of inflammation diseases.

The amount of hydrogen dissolved in saline is limited but it does have the effect of anti-inflammation. Our concentration used in the experiment has proved to be effective in curing other kinds of oxidant-stress related injury such as atherosclerosis[26] and type 2 diabetes [27]. Other scientists found that much lower concentration of hydrogen still has its effect[28]. So, the limited amount of hydrogen should be sufficient for exhibiting the anti-inflammation effect. Hydrogen may reach tissues by vessel conveying. The hydrogen is a liposoluble small molecular which can easily penetrate cell membrane, so it can be absorbed by mesenteric vessels and conveyed to any part of the body.

We found the anti-inflammation effects of hydrogen saline in a vivo inflammation model. Reportedly, carrageenan-induced paw edema is a highly sensitive tool to evaluate the efficacy of acute inflammation $[19,29]$. To decrease carrageenan-induced paw swelling by reducing levels of IL-8, IL-1 $\beta$, TNF- $\alpha$, NO via iNOS inhibition, and PGE2 via COX-2 inhibition, have all been documented $[30,31]$. In the present study, hydrogen saline showed dose-dependent inhibitory activity in carrageenan-induced paw edema.

The reason why we studied TNF- $\alpha$ secreted by macrophages is that, as an important inflammation mediator, TNF- $\alpha$ can reflect the degree of inflammation. Through the measurement of TNF- $\alpha$ we can come to the

Table 1 Effect of hydrogen saline on 3-NT and MPO activity

\begin{tabular}{cccc}
\hline Group & Time after carrageenan injecton & 3-NT(mOD/mg tissue) & MPO(nmol/L) \\
\hline Control & 4 hours & $8.03 \pm 1.96$ & $3.89 \pm 1.23$ \\
\hline CA & 4 hours & $53.91 \pm 4.11$ & $25.26 \pm 2.51$ \\
\hline CA+saline & 4 hours & $52.11 \pm 4.93$ & $24.35 \pm 3.07$ \\
\hline$H S 2.5 \mathrm{ml} / \mathrm{kg}$ & 4 hours & $43.88 \pm 3.12$ & $20.84 \pm 2.17$ \\
\hline$H S 5 \mathrm{ml} / \mathrm{kg}$ & 4 hours & $37.92 \pm 4.21$ & $14.88 \pm 1.89$ \\
\hline $\mathrm{HS} 10 \mathrm{ml} / \mathrm{kg}$ & 4 hours & $40.47 \pm 3.87$ & $21.92 \pm 2.52$ \\
\hline
\end{tabular}

Each value represents the mean \pm S.E.M. $n=7 .{ }^{*} \mathrm{p}<0.05{ }^{*} \mathrm{P}<0.01$ compared with $\mathrm{CA}+$ saline group. Student's $\mathrm{t}$-test after analysis of variance. CA $=$ carrageenan treatment. HS = carrageenan + hydrogen saline treatment. 


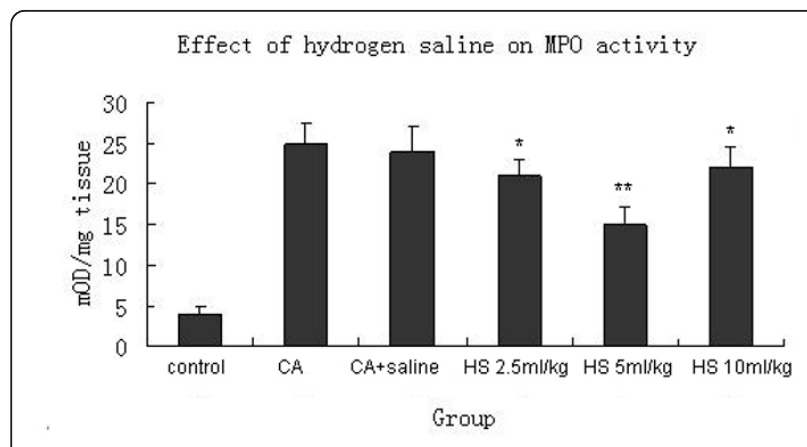

Figure 4 Effect of different dose of hydrogen saline administered intraperitoneally on myeloperoxidase activity in supernatants of homogenates from carrageenan-treated paws Paw myeloperoxidase activities were measured at $4 \mathrm{~h}$ after carrageenan treatment. Each bar represents the mean of 7 animals and vertical lines show the S.E.M. ${ }^{*} P<0.05$, ${ }^{*} P<0.01$. CA $=$ carrageenan treatment. $C A+$ saline $=$ carrageenan and saline treatment. $\mathrm{HS}=$ carrageenan and hydrogen saline treatment.

conclusion that the hydrogen saline has the anti-inflammation effect in cellular inflammation models. Furthermore, as mentioned above, TNF- $\alpha$ plays an important role in the process of inflammation[16,17]. Reducing the level of TNF- $\alpha$ has the effect of anti-inflammation in the animal model[32]. Therefore, the ability of hydrogen saline to suppress TNF- $\alpha$ production may be one of the factors that exert the anti-inflammation effect in the carrageenan induced paw oedema model.

Inflammation and free radicals have the relationship of mutual promotion. The inflammation can cause the increase of free radicals. Meanwhile, free radicals such as the hydroxyl radicals $\left({ }^{\circ} \mathrm{OH}\right)$ and peroxynitrogen $\left(\mathrm{ONOO}^{-}\right)$play an important role in the progress of inflammation, and inhibiting these free radicals can reduce the severity of inflammation. $\mathrm{H}_{2}$ molecule has a

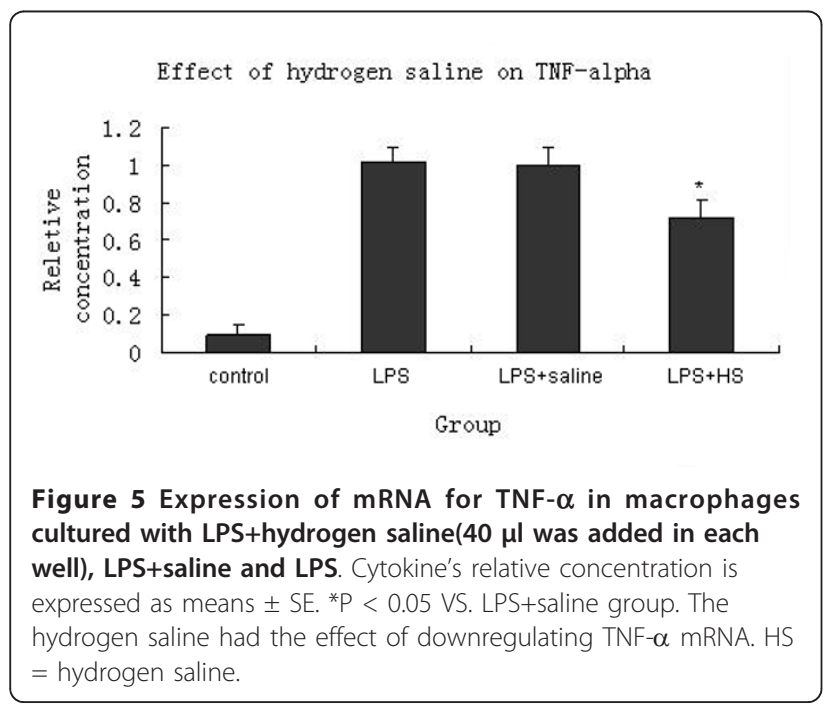

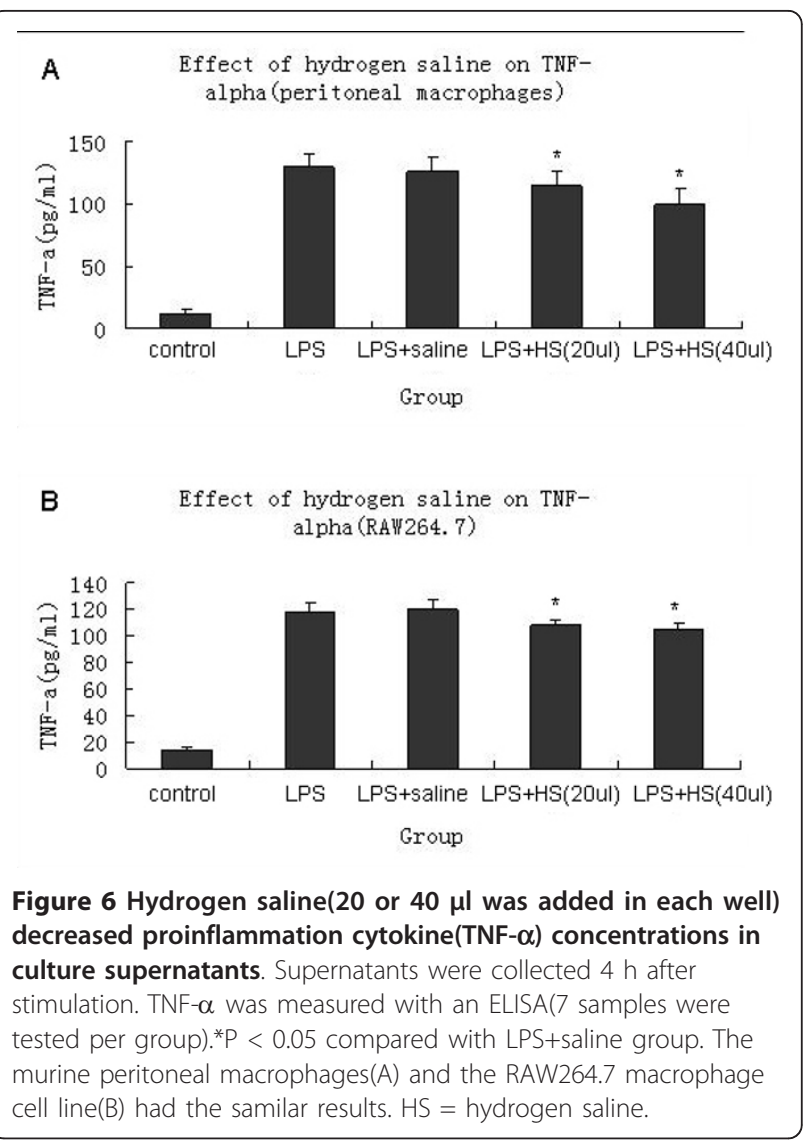

very strong covalent bond, so it can not easily react with all the oxidants. However, in recent studies, Ohsawa et al has found that molecular hydrogen can specifically reduce ${ }^{\circ} \mathrm{OH}$ and $\mathrm{ONOO}^{-}$in vitro and induce a therapeutic antioxidant effect in an animal model[12]. The $\mathrm{ONOO}^{-}$and ${ }^{\circ} \mathrm{OH}$ are the strongest oxidants and react indiscriminately with nucleic acids, lipids and proteins resulting in DNA fragment, lipid peroxidation, and inactivation of protein. $\mathrm{O}_{2}{ }^{-}$and $\mathrm{H}_{2} \mathrm{O}_{2}$ are detoxified by antioxidant defense enzymes, superoxide dismutase, and peroxidase or glutathione-peroxidase, respectively; however, no enzyme detoxifies ${ }^{\circ} \mathrm{OH}$ and $\mathrm{ONOO}^{-}$. Therefore, the ability of hydrogen saline to reduce or eliminate - $\mathrm{OH}$ and $\mathrm{ONOO}^{-}$may be responsible for the antiinflammation effect observed in this study. Our study suggests that hydrogen saline has the effects of antiinflammation and scavenging peroxynitrogen. As we know, hydrogen saline's direct and main effect is eliminating free radicals. So our results suggest that the antiinflammation effect of hydrogen saline may be caused by eliminating the free radicals.

Our study suggests that the effect of hydrogen at high concentration still has the anti-inflammation effect, though not as effective as $5 \mathrm{ml} / \mathrm{Kg}$. This bell shaped effect phenomenon is quite strange and its mechanism 
is not clear. The experiments of Ikuroh Ohsawa[12] also has the similar results, but it does not give the reason. We think that the bell shaped effect of 3-NT and MPO may play a role in the hydrogen's bell shaped effect of anti-inflammation. Furthermore, the negative feedback system may also play a role in the down-regulating antiinflammation effect of hydrogen. Meanwhile, the high concentration of hydrogen may affect the free radicals which are involved in the normal signal transduction system, and this may also explain the poor effect of anti-inflammation of hydrogen at high concentration. All the possible mechanisms are hypotheses which need to be proved in our future study.

Above all, we found that the hydrogen saline had the effect of anti-inflammation and the mechanism may work by reducing $\mathrm{ONOO}^{-}$. Furthermore, the down-regulated TNF- $\alpha$ production by macrophages may also play a role in the anti-inflammation effect. Although further investigations are still required to clarify the detailed mechanism, we could conclude that hydrogen saline is a potential candidate for the therapy of inflammatory diseases, which is more convenient to administer than inhaling hydrogen.

\section{Conclusion}

We found that the hydrogen saline has the effect of anti-inflammation to the carrageenan induced paw oedema and LPS-activated macrophages. Our results clearly demonstrate that hydrogen saline treatment exerts a protective effect and offers a novel therapeutic approach for the treatment of inflammation diseases.

\section{Acknowledgements \\ The work was supported by National Natural Science Foundation of China (30971199). \\ We thank Danfeng Fan (second military medical university), Juan Zheng (second military medical university) for their technical assistance.}

\section{Authors' contributions}

ZX carried out the animal experiment and drafted the manuscript. JZ carried out the immunoassays and real-time PCR test. JC and ZZ participated in the MPO and 3-NT test. XS participated in the design of the study and performed the statistical analysis. CJ conceived of the study, and participated in its design and coordination. All authors read and approved the final manuscript.

\section{Competing interests}

The authors declare that they have no competing interests.

Received: 20 August 2010 Accepted: 2 February 2012 Published: 2 February 2012

\section{References}

1. Cuzzocrea Salvatore, Mazzon Emanuela, Dugo Laura, Serraino Ivana, Ciccolo Antonio, Centorrino Tommaso, De Sarro Angela, Achille pCaputi: Protective effects of n-acetylcysteine on lung injury and red blood cell modification induced by carrageenan in the rat. The FASEB Journal 2001, 15:1187-200.
2. Salvemini D, Wang ZQ, Bourdon DM, Stern MK, Currie MG, Manning PT: Evidence of peroxynitrite involvement in the carrageenan-induced rat paw edema. Eur J Pharmacol 1996, 303:217-20.

3. Cuzzocrea S, Zingarelli B, Costantino G, Szabó A, Salzman AL, Caputi AP, Szabó C: Beneficial effects of 3-aminobenzamide, an inhibitor of poly (ADP-ribose)synthetase in a rat model of splanchnic artery occlusion and reperfusion. Br JPharmacol 1997, 121:1065-74

4. Tracey WR, Nakane M, Kuk J, Budzik G, Klinghofer V, Harris R, Carter G: The nitric oxide synthase inhibitor, L-NG-monomethylarginine, reduces carrageenan-induced pleurisy in the rat. J Pharmacol Exp Ther 1995, 273:1295-9.

5. Wei XQ, Charles IG, Smith A, Ure J, Feng GJ, Huang FP, Xu D, Muller W, Moncada S, Liew FY: Altered immune responses in mice lacking inducible nitric oxide synthase. Nature (Lond) 1995, 375:408-11.

6. Salvemini D, Wang ZQ, Wyatt P, Bourdon DM, Marino MH, Manning PT, Currie MG: Nitric oxide: A key mediator in the early and late phase of carrageenan-induced rat paw inflammation. Br J Pharmacol 1996, 118:829-38.

7. Miller MJ, Thompson JH, Zhang XJ, Sadowska-Krowicka H, Kakkis JL, Munshi UK, Sandoval M, Rossi JL, Eloby-Childress S, Beckmann JS: Role of inducible nitric oxide synthase expression and peroxynitrite formation in guinea pig ileitis. Gastroenterology 1995, 109:1475-83.

8. Chamulitat W, Skrepnik NV, Spitzer JJ: Endotoxin-induced oxidative stress in the rat small intestine: Role of nitric oxide. Shock 1996, 5:217-22.

9. Kaur $H$, Halliwell B: Evidence for nitric oxide-mediated oxidative damage in chronic inflammation: Nitrotyrosine in serum and synovial fluid from rheumatoid patients. FEBS Lett 1994, 350:9-12.

10. Rachmilewitz D, Stamler JS, Karmeli F, Mullins ME, Singel DJ, Loscalzo J, Xavier RJ, Podolsky DK: Peroxynitrite-induced rat colitis: A new model of colonic inflammation. Gastroenterology 1993, 105:1681-8.

11. Sheu SS, Nauduri D, Anders MW: Targeting antioxidants to mitochondria: a new therapeutic direction. Biochim Biophys Acta 2006, 1762:256-65.

12. Ohsawa Ikuroh, Ishikawa Masahiro, Takahashi Kumiko, Watanabe Megumi, Nishimaki Kiyomi, Yamagata Kumi, Katsura Ken-ichiro, Katayama Yasuo, Asoh Sadamitsu, Ohta Shigeo: Hydrogen acts as a therapeutic antioxidant by selectively reducing cytotoxic oxygen radicals. Nature Medicine 2007, 13:688-94.

13. Kajiya M, Sato K, Silva MJ, Ouhara K, Do PM, Shanmugam KT, Kawai T: Hydrogen from intestinal bacteria is protective for Concanavalin Ainduced hepatitis. Biochem Biophys Res Commun 2009, 386(2):316-21.

14. Kajiya M, Silva MJ, Sato K, Ouhara K, Kawai T: Hydrogen mediates suppression of colon inflammation induced by dextran sodium sulfate. Biochem Biophys Res Commun 2009, 386(1):11-5, Aug 14;386(1):11-5. 2009.

15. Yanagihara T, Arai K, Miyamae K, Sato B, Shudo T, Yamada M, et al: Electrolyzed hydrogen saturated water for drinking use elicits an antioxidative effect: a feeding test with rats. Biosci Biotechnol Biochem 2005, 69:1985-7.

16. Myoung Shin Eun, Yu Zhou Hong, Yu Guo Lian, Ah Kim Jeong, Ho Lee Seung, Merfort d Irmgard, Sik Kang Sam, Sung Kim Hak, Kim Sanghee, Shik Kim Yeong: Anti-inflammation effects of glycyrol isolated from Glycyrrhiza uralensis (Leguminosae) in LPS-induced RAW264.7 macrophages. Int Immunopharmacol 2008, 10:1016-25.

17. Mazzon E, Esposito E, Di Paola R, Muià C, Crisafulli C, Genovese T, Caminiti R, Meli R, Bramanti P, Cuzzocrea S: Effect of tumour necrosis factor-alpha receptor 1 genetic deletion on carrageenan-induced acute inflammation: a comparison with etanercept. Clin Exp Immunol 2008, 153:136-49.

18. Cai Jianmei, Kang Zhimin, Liu Kan, Liu WenWu, Li RunPing, H John Zhang, Luo Xu, Sun Xuejun: Neuroprotective Effects of Hydrogen Saline in Neonatal Hypoxia-ischemia Rat Model. Brain Research 2008, doi:10.1016.

19. Morris CJ: Carrageenan-induced paw edema in the rat and mouse. Methods Mol Biol 2003, 225:115-221.

20. Recio MC, Ginet RM, Uribun L, Manez S, Cerda M, De La Fuente JR, Rios JL: In vivo activity of pseudoguaianolide sesquiterpene lactones in acute andchronic inflammation. Life Sciences 2000, 66:2509-18.

21. Kim GY, Choi GS, Lee SH, Park YM: Acidicpolysaccharide isolated from Phellinus linteus enhances through the up-regulation of nitric oxide and tumor necrosis factor-afrom peritoneal macrophages. J Ethnopharmacol 2004, 95:69-76.

22. Park Pil-hoon, R McMullen Megan, Huang Honglian, Thakur Varsha, E Nagy Laura: Short-term Treatment of RAW264.7 Macrophages with 
Adiponectin Increases Tumor Necrosis Factor- a (TNF- a) Expression via ERK1/2 Activation and Egr-1 Expression. The Journal Of Biological Chemistry 2007, 282:21695-703.

23. Raadan ODBILEG, Satoru KONNAI, Tatsufumi USUI, Kazuhiko OHASHI and Misao ONUMA: Quantification of Llama Inflammatory Cytokine mRNAs by Real-Time RT-PCR. J Vet Med Sci 2005, 67:195-8.

24. Simpson DA, Feeney S, Boyle C, Stitt AW: Retinal VEGF mRNA measured by SYBR green I fluorescence: A versatile approach to quantitative PCR. Molecular Vision 2000, 6:178-83.

25. Choy CS, Hu CM, Chiu WT, Lam CS, Ting Y, Tsai SH, Wang TC: Suppression of lipopolysaccharide-induced of inducible nitric oxide synthase and cyclooxygenase- 2 by Sanguis Draconis, a dragon's blood resin, in RAW 264.7 cells. J Ethnopharmacol 2008, 115:455-62.

26. Ohsawa Ikuroh, Nishimaki Kiyomi, Yamagata Kumi, Ishikawa Masahiro, Ohta Shigeo: Consumption of hydrogen water prevents atherosclerosis in apolipoprotein E knockout mice. Biochemical and Biophysical Research Communications 2008, 377:1195-1198.

27. Kajiyama Sizuo, Hasegawa Goji, Asano Mai, Hosoda Hiroko, Fukui Michiaki, Nakamura Naoto, Kitawaki Jo, Imai Saeko, Nakano Koji, Ohta Mitsuhiro, Adachi Tetsuo, Obayashi Hiroshi, Yoshikawa Toshikazu: Supplementation of hydrogen-rich water improves lipid and glucose metabolism in patients with type 2 diabetes or impaired glucose tolerance. Nutrition Research 2008, 28:137-143.

28. Fujita Kyota, Seike Toshihiro, Yutsudo Noriko, Ohno Mizuki, Yamada Hidetaka, Yamaguchi Hiroo, Sakumi Kunihiko, Yamakawa Yukiko, A Kido Mizuho, Takaki Atsushi, Katafuchi Toshihiko, Tanaka Yoshinori, Nakabeppu Yusaku, Noda Mami: Hydrogen in Drinking Water Reduces Dopaminergic Neuronal Loss in the 1-methyl-4-phenyl-1,2,3,6tetrahydropyridine Mouse Model of Parkinson's Disease. PLOS ONE 2009, 4(9):e7247.

29. Lallouette P, Richou R, Schwartz A, Richou H: Anti-inflamma-tory activity of inflammatory substances. General action of carrageenan on various acute inflammation models. C R Acad Sci Hebd Seances Acad Sci D 1970, 270:876-8.

30. Park H, Kim YH, Chang HW, Kim HP: Anti-inflammation activity of the synthetic C-C biflavonoids. J Pharm Pharmacol 2006, 58:1661-7.

31. Park HJ, Kim IT, Won JH, Jeong SH, Park EY, Nam JH: Anti-inflammatory activities of ent-16alphaH,17-hydroxy-kauran-19-oic acid isolated from the roots of Siegesbeckia pubescens are due to the inhibition of iNOS and COX-2 expression in RAW 264.7 macrophages via NF-kappaB inactivation. Eur J Pharmacol 2007, 558:185-93.

32. Malleo G, Mazzon E, Genovese T, Di Paola R, Muià C, Centorrino T, Siriwardena AK, Cuzzocrea S: Etanercept attenuates the development of cerulein-induced acute pancreatitis in mice: a comparison with TNFalpha genetic deletion. Shock 2007, 27:542-51.

doi:10.1186/1476-9255-9-2

Cite this article as: Xu et al:: Anti-inflammation effects of hydrogen saline in LPS activated macrophages and carrageenan induced paw oedema. Journal of Inflammation 2012 9:2.

\section{Submit your next manuscript to BioMed Central and take full advantage of:}

- Convenient online submission

- Thorough peer review

- No space constraints or color figure charges

- Immediate publication on acceptance

- Inclusion in PubMed, CAS, Scopus and Google Scholar

- Research which is freely available for redistribution 